objection to any of them was taken on any ground affecting them individually, but only on the general ground that all of them were members of the Congress Party. I cannot regard the learned trial judge as having been in error when he disallowed this objection."

[Contributed by Mr. J. B. V. Nyimba]

\title{
Fifth Commonwealth Magistrates' Conference, Oxford, 1979
}

The Commonwealth Magistrates' Association, whose first conference was held in London in 1970 , is by now well established, with members in a number of Commonwealth African countries. Its Fifth Conference, held at Christchurch, Oxford from 23rd to 29th September, 1979, was open to magistrates and judges from the Commonwealth. Judged on the basis of the number of Commonwealth countries, great and small, represented, this was the most successful of the conferences so far. All Commonwealth African countries were among those with strong delegations.

The Conference had the privilege of being opened by the Lord High Chancellor of Great Britain, the Right Honourable the Lord Hailsham of St Marylebone, who gave a trenchant address directed, as one might have expected, at the concept of justice and the duty of the courts to maintain it. The General Assembly of the Association had the further privilege of being addressed by the Master of the Rolls, the Right Honourable the Lord Denning, in his own inimitable style. Lord Denning is, of course, no stranger to Africa and to the legal profession there; and is in addition an Honorary Life Vice-President of the Association.

The general theme of the Conference was "The Citizen and the Law", an attempt to look at the work of the courts, and of legal agencies generally, from the point of view of the persons (the "customers") who make use of them. There were five main topics for discussion, each of which provoked a lively debate as well as an invaluable opportunity to compare notes: the citizen and the police; the citizen and his right to liberty-bail and remand; the citizen and his right to legal aid; the role of the layman as judge, juryman, or assessor in criminal trials; and court standards, which covered both how trials are conducted as well as the physical facilities available for them.

12 August, 1979.

2 Resident High Court Judge at Kisumu.

Emphasis added.

Law of Succession Act, No. 14 of 1972. 